\title{
Public perceptions of shale gas in the UK: framing effects and decision heuristics
}

\author{
Harry McNally ${ }^{1} \cdot$ Peter Howley $^{2} \cdot$ Matthew Cotton $^{1}$ \\ ${ }^{1}$ Environment Department, University of York, Heslington, York YO10 5DD, UK \\ ${ }^{2}$ Leeds University Business School, University of Leeds, Leeds LS2 9JT, UK
}

Received: 16 January 2018/Revised: 31 May 2018/Accepted: 5 September 2018/Published online: 14 September 2018

(C) The Author(s) 2018

\begin{abstract}
Using two equivalent descriptions of the shale gas development process, we asked individuals to indicate their levels of support as well as their perceptions of the risks and costs involved. In version 1, shale gas development was framed as 'fracking', whereas under version 2 it was framed as 'using hydraulic pressure to extract natural gas from the ground'. We find that individuals' support for shale gas development is much lower when using the term 'fracking' as opposed to the synonymous descriptive term, and moreover, these differences were substantive. Our analysis suggests that these differences appear to be largely the result of different assessments of the risks associated with 'fracking' as opposed to 'using hydraulic pressure to extract natural gas from the ground'. Our proposed explanation for these differences rests on the idea that shale gas development is a technical and complex process and many individuals will be bounded by the rationality of scientific knowledge when it comes to understanding this process. In turn, individuals may be relying on simple decision heuristics shaped by the way this issue is framed by the media and other interested parties which may constrain meaningful discourse on this topic with the public. Our findings also highlight some of the potential pitfalls when it comes to relying on survey research for assessing the public's views towards complex environmental issues.
\end{abstract}

Keywords Fracking $\cdot$ Framing effects $\cdot$ Energy $\cdot$ Shale gas exploration

Matthew Cotton

matthew.cotton@york.ac.uk

\section{Introduction}

Technological advancements in the horizontal drilling and slickwater hydraulic fracturing of permeable shales, tight sands and coalbeds, have created favourable economic conditions for 'unconventional' oil and gas (hereafter UOG) development. Collectively, these technologies have stimulated a so-called 'shale boom' in the USA and prompted political interest in the potential economic and energy security-of-supply benefits in certain European Member States, notably Denmark, Poland and the UK.

Since 2012, under the former Coalition Government, a policy platform of 'going all out for shale' has been supported by measures to stimulate shale gas investment: including $100 \%$ business rate recovery from UOG operations for local authorities, industry tax incentives and community benefits packages for shale gas host communities (Cotton et al. 2014). Though the Conservative Government espouses the economic benefits from shale gas exploration, critics continue to argue that shale extraction has significant environmental impacts. Notable concerns here include water availability and water stress, groundwater contamination with thermogenic methane and hydraulic fracturing fluid additives, treatment of waste water returns containing (among other things) naturally occurring radioactive materials (NORM) (Osborn et al. 2011; DiGiulio and Jackson 2016; Vandecasteele et al. 2015; Birdsell et al. 2015; Siegel et al. 2015) and atmospheric pollution from fugitive methane emissions and flaring (Howarth et al. 2011b; Sovacool 2014).

These collective impacts are of public health concern because exposure is associated with nervous system, respiratory and gastrointestinal health risks, cancer risks 
(Kovats et al. 2014) and increased incidence of infant mortality (Busby and Mangano 2017). Other environmental impacts include induced seismicity (The Royal Society and The Royal Academy of Engineers 2012; Holland 2013; Ellsworth 2013; Clarke et al. 2014), light and noise pollution and road traffic collisions. Socio-economic impacts such as impacts on rural industrialisation (Brasier et al. 2011), long-term psycho-social stress (Ferrar et al. 2013) leading to issues such as depression and substance abuse (Perry 2012), are also of concern to many.

Though water and point-source pollution effects dominate public conceptualisations of risk in the USA (Thomas et al. 2017), in the UK shale gas debates centred upon seismic activity resulting from UOG operations by Cuadrilla $^{1}$ in 2011. Specifically, seismic shocks weighing in at $1.5 \mathrm{ML}$ and $2.3 \mathrm{ML}$ on the Richter scale were recorded (Clarke et al. 2014). To put this into context, earthquakes of this size are generally not felt 'except by a very few, under especially favourable conditions'. Despite the relatively low magnitude of these shocks, induced seismicity has become one of the most significant fears for British citizens when it comes to shale gas exploration. However, recent research shows a shift from local (concerning things such as seismic activity) to global frames (Hilson 2015) and how climate change impacts from UOG development relate to energy system transitions (including other low carbon transitions to renewable energy) within public dialogue (Partridge et al. 2017).

Despite local social movements of opposition around key unconventional oil and gas sites (notably Preston New Road in Lancashire), the UK Government remains in favour of extraction activities. Political statements of support commonly cite reports by The Royal Society and The Royal Academy of Engineers (2012), Public Health England (2013) and the Tyndall Centre (Broderick et al. 2011)_arguing that any risks associated with shale gas development can be contained with sensible, robust and pre-emptive regulations. Yet Government-level support stands in opposition to broader public opinion. Polling by the former Department of Energy and Climate Change (DECC), found that just $19 \%$ of surveyed households were in favour of shale gas exploration, whereas $31 \%$ voiced opposition (DECC 2016) (it must be noted, however, that there was a high proportion of 'don't know' and 'neither support or oppose' responses in these surveys, suggestive of a knowledge gap about UOG by the UK public at this time). Such attitudes are strongly influenced by demographic, political affiliation and environmental values

\footnotetext{
${ }^{1}$ Cuadrilla Resources carried out the UK's first 'fracking' tests at Presse Hall near Blackpool in 2011. The earthquakes on 27 May and 1 April were strongly linked to Cuadrilla's operations in both the DECC report (2014) and the independent report commissioned by Cuadrilla Resources (Pater and Baisch 2011).
}

(Whitmarsh et al. 2015), but also by non-environmental considerations such as trust in political and industry authorities (Christopherson et al. 2013; Bomberg 2015) and issues of social and environmental justice in planning processes for new sites (Cotton 2015; Whitton et al. 2017). Thomas et al. (2017) find in their review of the social science of UOG development that the technology itself is highly contested, politicised and raises questions about what constitutes 'acceptable' risk in different social and geographic contexts. We answer their call for nuanced inquiry that employs a range of methodologies in order to explore perceptions in the social and geographical context of York-a community that is subject to imminent UOG development in its locality.

\subsection{Public understanding of unconventional oil and gas exploration}

A persistent question remains as to how non-specialist citizen-stakeholders (or 'publics') interpret shale gas exploration, and the basis upon which they ground such understanding. Shale gas development is a technical process with a multitude of both potential benefits and costs. Government strategy to date has been largely grounded in a deficit model in which a technical approach to feasibility and safety, and one-way communication of said safety is deemed enough for good policy-making, though as Williams et al. (2017) deliberative focus group research suggests: public unease cannot be explained by lack of understanding alone. Despite this, however, it is reasonable to suggest that widespread limits on technical reasoning may force individuals to rely on unreliable cognitive heuristics when it comes to evaluating the merits of hydraulic fracturing. Rather than being shaped by the best available science, these cognitive heuristics may in turn be shaped by public or media discourse in this area. This can be problematic as studies on media representation of this issue have found that shale gas development is often presented through conflict, blame and environmental damage, while often leaving out other important aspects (Habib and Hinojosa 2016).

One important factor shaping public perceptions of fracking is the language used to frame the concept and its associated impacts (for discussion of framing see for example Davis 1995). Notably there is controversy over the word 'fracking' itself, which is commonly used to represent the UOG development process. The word has come to carry negative connotations for people, and recent survey research in the USA by Evensen et al. (2014a) found that the word 'fracking' was likely to take on multiple meanings and evoke negative and lewd connotations. Also in the USA, Climek et al. (2013) find that the word 'frack' in survey questions can decrease by $12 \%$ the number of 
respondents who support hydraulic fracturing. Evensen et al.'s work contrasts with that of Stoutenborough et al. (2016), however, that asserts that this effect is potentially overstated (Stoutenborough et al. 2016). In the context of UK UOG development, this effect of word choice when it comes to assessing the general publics' views on UOG development requires further study.

We posit an explanation for observed differences in the public's assessment of UOG development based on word choice (i.e. the use of the word fracking) which draws on research in psychology which suggests that individuals undergo two discrete forms of information processing: 'System 1', which is automatic, uncontrolled and effortless-involving rapid visceral judgments that manifest themselves in various decision-making 'heuristics'; and 'System 2', which is controlled, slow and conscious and requires conscious reflection and calculation (Dolan et al. 2012; Kahan et al. 2012). Partly owing to the dominance of the rational choice paradigm, it has traditionally been assumed that preferences conform to formal decisions of rationality, i.e. individuals engage in systematic and deep analysis. Behavioural economists have, however, documented a number of instances where individuals rely on simple heuristics which can result in behaviour that would appear to act against their own rational self-interest (Jolls et al. 1998; Dolan et al. 2012; Kahneman and Tversky 1984).

We hypothesise that many individuals are bounded by the rationality of scientific knowledge when it comes to understanding shale gas development and may be relying on simple heuristics (System 1) when formulating their preferences. These decision heuristics in turn may be shaped by non-scientific as well as scientific considerations, including linguistic influences and popular (if scientifically controversial) representations in print and televised media, e.g. the Gasland documentary ${ }^{2}$ which raised safety concerns surrounding the extraction of shale deposits. Discourses such as 'dirty-versus-clean' representations of shale extraction (when compared to coal and renewables, respectively) (Cotton et al. 2014) have considerable influence upon citizen-stakeholder understanding (Cotton 2015), and even the word 'frack' itself is commonly used in popular culture for similar sounding obscenities (Evensen et al. 2014a). Various local activist

\footnotetext{
2 The film 'Gasland' was directed by Josh Fox in 2010 and follows the story of a Pennsylvanian homeowner and his research into the hydraulic fracturing industry. It links 'fracking' to air and water contamination problems, with striking scenes of flammable drinking water in American homes. A heated discourse ensued with the Independent Petroleum Association of America (IPAA) and researchers from the University of Colorado among others. The concerns raised in the movie continue to fuel unease among surveyed citizens (Borick et al. 2014; Theodori 2009; Andersson-Hudson 2016).
}

groups also often use the work 'fracking' in a deliberately pejorative way, e.g. one activist groups labels itself as Frack Off as a framing effect specifically to conjure negative connotations in the receiver's mind.

In order to test this hypothesis, we employed a split survey sample technique where two comparable groups of the general public were asked to indicate their levels of support for shale gas exploration, and to assess the risks and costs involved, but using two different questionnaire formats. Version 1 used the more colloquial phrase 'fracking' when gauging public attitudes, whereas version 2 refers to shale gas development as 'using hydraulic pressure to extract natural gas from the ground'. We find that individuals' support for 'fracking' is much lower than 'using hydraulic pressure to extract natural gas from the ground', and moreover, these differences were substantive. Our analysis also suggests that these differences appear to be largely the result of different risk perceptions, i.e. respondents feel that the risks associated with 'fracking' are much greater than with 'using hydraulic pressure to extract natural gas from the ground'.

These findings could have significant implications when it comes to communicative actions within the debate surrounding the development of shale gas development in the UK, as our results suggest that using the word 'fracking', which is perhaps the most common mechanism used to represent the shale gas development issue towards the general public, may evoke negative connotations and bias. More generally, our results highlight some of the potential pitfalls when it comes to relying on survey research for assessing the public's views towards complex environmental issues.

\section{Background}

\subsection{Attitudes towards shale gas exploration}

In the USA, the proliferation of the shale industry has leased a new era of profitability (NERA 2012; Citi GPS 2012). On a national and global scale, the economic benefits are salient; the USA now exerts significant influence and control over oil and gas markets overseas, and domestic prices are plummeting. Some UOG optimism is also evident in the UK with certain stakeholders recognising that European gas prices exceed those in the USA and therefore provide greater scope for production increases to generate revenue (Cotton et al. 2014). At a national level, the aggregation of small economic benefits provides a distinct picture of what UOG development can engender. However, at a local level, these positive economic impacts are, understandably, harder to see, as while at a national level there may be significant economic benefits, any costs 
will be concentrated in the local communities themselves (Whitmarsh et al. 2015; Borick et al. 2014) so may be understated in public perception studies.

Aside from perceived economic benefits, it has been speculated that shale gas could act as a 'transition fuel' to a cleaner renewable future (Argetsinger 2011; Davis and Shearer 2014; Hultman et al. 2011; Levi 2013; Wu et al. 2016). Since 2005, US $\mathrm{CO}_{2}$ emissions have fallen at an average annual rate of $1.4 \%$ accompanied by a $48 \%$ increase in dry natural gas production driven by an expanding shale gas industry (EIA 2017a, b). In 2012, UK public perceptions of shale gas were net positive, spurred on by excitement surrounding cleaner energy compared to other hydrocarbons (Andersson-Hudson 2016). However, in the 3 years following the 2013 protests in Balcombe, Sussex, ${ }^{3}$ clean energy optimism plummeted by $23 \%$ (Andersson-Hudson 2016).

Public apprehension concerning social problems is another common theme throughout relevant literature (Brasier et al. 2011; Borick et al. 2014; Cotton et al. 2014). The shale gas industry provides employment and, by extension, a stimulus for rapid population growth of rural settlements (dubbed 'energy boomtowns'). North American literature frequently refers to the negative social impacts associated with 'energy boomtowns'; these include soaring crime rates, alcoholism, low school enrolment and schisms between 'Old Timers' and 'Newcomers' (Kohrs 1974; Thompson 1979; Brasier et al. 2011; Schafft et al. 2013). Perceptions of local economic benefits are therefore potentially negated by associated social problems (see in particular Jacquet 2014). At the time of writing, most shale extraction activities are at the exploration, rather than commercial extraction level, and so rapid employment expansion to isolated rural locations has not (yet) occurred. A lack of boomtown-related concerns in UK public perceptions might therefore represent a gap in public awareness of the real socio-economic consequences of hydraulic fracturing.

\subsection{Media use and related perceptions}

When it comes to the communication of scientific information to the public, the role of the media is paramount (Young and Dugas 2011; Olive 2016; Entman 1993). Newspapers are commercial enterprises and are therefore tailored towards customers' interests, beliefs and politics (Gentzkow and Shapiro 2006; Baron 2006). On this basis, it is interesting to examine whether public perceptions of

\footnotetext{
${ }^{3}$ In 2012, anti-fracking protests began in opposition to proposed drilling and hydraulic fracturing at a site near Balcombe (a village in West Sussex). These demonstrations became exacerbated when in 2013 Cuadrilla Resources obtained a licence to drill at the site and marked an important change in national 'fracking' optimism.
}

media credibility match those of the scientific community. A survey conducted by Borick et al. (2014) required individuals to identify the most credible source of information on hydraulic fracturing, and this study revealed a striking mistrust of newspapers and Government websites. Despite generalised mistrust of media reporting, newspapers contribute more to public understanding of hydraulic fracturing than the energy industry, regulators and environmental groups, as shown in regional newspaper analyses (Theodori et al. 2014). It must also be noted that regional differences in reporting occur as Ashmoore et al.'s (2016) study across Ohio, Pennsylvania and New York shows. There is considerable diversity and nuance across the regional discourses of shale gas development produced by media reporting. Perceptions are influenced by different cultural and national contexts. This is noteworthy because British newspapers received criticism for their portrayal of hydraulic fracturing in one comprehensive study by Jaspal and Nerlich (2013).

Interview responses from one British study reveal perceptions of issue portrayal in newspapers that emulate Jaspal and Nerlich's (2013) conclusions: specifically that the media frame the $\mathrm{CO}_{2}$ and methane footprint of UOG relative to cleaner resources in each regard (Cotton et al. 2014). Such '....counter-discourse...is defined by...higher methane emissions relative to coal and higher $\mathrm{CO}_{2}$ (emissions) in relative terms to renewable energy resources' (ibid.). Though controversy surrounding increased, methane emissions emerged following Howarth et al.'s (2011a, b) study; the general scientific consensus is that the climate-related impacts of methane emissions from hydraulic fracturing tend to be unconfirmed (Siegel et al. 2015) and key $\mathrm{CO}_{2}$-related benefits relative to coal are omitted, with the overall effects on global-mean temperature over the twenty-first century being very small (Wigley 2011).

As Williams et al. (2017) have argued, public acceptance of hydraulic fracturing is assumed to be limited only by a lack of transparent communication of the risks and benefits to communities-i.e. 'a primary recommendation...is that open and full communication is paramount' (Theodori 2009). However, issues of trustworthiness and inclusivity may play an equally important role in explaining public opposition. It is conceivable that deep rifts between institutional actors and British citizens prevent impartial judgement on the merits and drawbacks of hydraulic fracturing (Williams et al. 2017). Trustworthiness is particularly important for the UOG industry as impacts are intangible. Water contamination, fugitive methane emissions and seismicity are socio-culturally 'invisible' risks to the public, and their presence is therefore dictated by information released by private institutions (e.g. IGas Energy Plc) and public-sector regulators (e.g. 
Environment Agency). Cotton et al. (2014) therefore argue that a lack of social licence to operate (an intangible social contract of trust between developer and community) fosters opposition to hydraulic fracturing.

Cuadrilla Resource's council application for a Lancashire-based well in 2009 was a typical example of institutional duplicity that may have prompted mistrust on behalf of British citizens. By declaring an exploratory area of 0.99 ha (under the 1 ha benchmark) and stating that they had no commercial intentions for the well, Cuadrilla Resources were exempt from an independent Environmental Impact Assessment (EIA) required as part of the Town and Country Planning Regulations of 1999 (Cotton et al. 2014). Cotton (2017) argues that an EIA manifests itself as a form of social and environmental justice, and by deliberately employing evasive tactics, Cuadrilla fostered immediate mistrust of the company and, most importantly, the UOG industry itself. Therefore, it is possible that opposition is based less on a well-founded examination of the facts and more by the link it has with other institutions within industry and Government.

\section{Data collection}

We conducted face-to-face questionnaires with residents in York, a city within in the Northeast of England. York is an ideal study site given its involvement in shale-related decisions in Ryedale, North Yorkshire, the local coverage of land areas by Petroleum Exploration and Development Licenses (PEDL), the widespread coverage of shale decisions in the local press, and the prevalence of anti-shale gas social movements of opposition. The surveys first collected basic socio-demographic information. Other questions pertained to respondents' media use, environmental attitudes and awareness of the Government's stance on the issue of shale gas exploration. Next, respondents were asked a series of questions relating to their levels of support for shale gas exploration. For this part of the survey, we employed a split sample technique to test to what extent (if any) support for shale gas development differed depending on how the issue was framed for respondents.

In version 1 of the questionnaire $(n=100)$, respondents were asked whether they support fracking, whether they believed there were any risks and to rate the severity of those risks and finally what do they think is greater-the benefits or costs of fracking? Respondents were also asked open-ended questions relating to what they viewed as being the major advantages and disadvantages of fracking. In version 2 ( $n=100)$, instead of using the term 'fracking' we instead used a different, non-'fracturing' focused phrase: 'using hydraulic pressure to extract natural gas from the ground', which is scientifically accurate but frames the processes involved in a different way. The surveys themselves are not meant to provide a nationally representative view of public attitudes towards UOG development. Rather, the aim is to contribute to the literature on framing, linguistics, word choice and knowledge in relation to the controversial energy issue of shale gas development. Specifically, by conducting the surveys in the same area and using random assignment when it comes to distributing questionnaire formats, we can test how responsive individuals are to question wording, i.e. differences in support for 'fracking' versus a non-'fracturing' focused phrase: 'using hydraulic pressure to extract natural gas from the ground', which is scientifically accurate but frames the processes involved in a different way.

In order to ensure that both groups were mutually comparable, we conducted the surveys in the same area and alternated the distribution of each version of the questionnaire after each interview. It is still of course possible (albeit unlikely given the random assignment of questionnaires) that any observed differences between each version of the questionnaire could at least be partly due to differences in the types of individuals surveyed in each group. That is, any observed differences between individuals support for shale gas development when faced with 'fracking' as opposed to 'using hydraulic pressure to extract natural gas from the ground' could be the result of differences in the types of individuals surveyed for each version of the questionnaire. However, we find no significant differences between both groups of survey respondents. For instance, we found no significant difference in the age, gender and educational profile of respondents across both survey groups (version 1 and 2) and respondents were also very similar when it came to levels of overall environmental concern and political orientation. This means that any observed differences in support for 'fracking' (version 1) versus 'hydraulic pressure' (version 2) are not the result of any differences in the composition of both survey groups. In the analysis that follows, we first test to see if there are any particular characteristics of individuals that make them more or less likely to support shale gas development before moving on to a more detailed examination of respondents' attitudes towards shale gas development under the two different questionnaire formats.

\section{Results}

\subsection{Multivariate analysis}

Table 1 presents the results of a multivariate regression analysis where we examined what factors were related with support for shale gas development. In version 1 of the questionnaire, respondents were asked whether they 
Table 1 Support for shale gas exploration

\begin{tabular}{|c|c|c|c|c|c|c|}
\hline & \multicolumn{2}{|l|}{ Spec 1.} & \multicolumn{2}{|l|}{ Spec 2.} & \multicolumn{2}{|l|}{ Spec 3.} \\
\hline & Coef. & SE & Coef. & SE & Coef. & SE \\
\hline Version & $-0.45^{* * *}$ & 0.15 & $-0.43 * * *$ & 0.15 & -0.16 & 0.15 \\
\hline Age & & & 0.07 & 0.07 & 0.05 & 0.07 \\
\hline Males & & & 0.09 & 0.16 & -0.03 & 0.15 \\
\hline Has a degree & & & $0.28 *$ & 0.16 & $0.26^{*}$ & 0.16 \\
\hline Environmental values & & & $-0.29 * * *$ & 0.07 & $-0.25 * * *$ & 0.07 \\
\hline Political orientation-conservative & & $0.72 * * *$ & 0.16 & $0.66 * * *$ & 0.16 & \\
\hline Risk perception & & & & & $0.12 * * *$ & 0.03 \\
\hline$R$ squared & 3.6 & & 21.49 & & 28.96 & \\
\hline
\end{tabular}

*Statistically significant at $10 \%, * *$ significant at $5 \%, * * *$ significant at $1 \%$ support 'fracking', and in version 2, they were asked whether they support 'using hydraulic pressure to extract natural gas from the ground'. For both versions, respondents were given a 5 point scale ranging from 1 strongly against to 5 strongly in favour, and with a view towards improving statistical precision given the relatively limited sample size, we pooled both versions into one variable which we label as support for shale gas development. We then tested if we could find any significant differences in the levels of support for shale gas development based on socio-demographic factors, political ideology, environmental values and risk perceptions (see Table 1). Support for shale gas development is reported on an ordinal scale. For ease of reporting, we assume cardinality and use ordinary least squares when examining the relationship between our variables of interest. However, in an unreported robustness check (available on request), we also used logistic regression (ordered logistic) when examining what factors were related with shale gas development and we found no substantive difference between the two approaches (OLS and logistic regression).

In our first specification, we simply regressed version (which represented which version of the questionnaire respondents received) on support for shale gas exploration. We find, as expected, that overall support for shale gas development is significantly lower $(-0.45)$ when respondents are presented with the questionnaire version relating to 'fracking' as opposed to 'using hydraulic pressure to extract natural gas from the ground'. In specification 2, we added in socio-demographic variables, a dummy variable capturing whether respondents regard themselves as conservative in terms of their political beliefs and finally a measure of environmental values. We can see that our variable version capturing which version of the questionnaire respondents received is largely unaffected by the addition of these additional explanatory variables. This suggests that these explanatory variables do not explain the difference in support for shale gas development when using the term 'fracking' as opposed to 'using hydraulic pressure to extract natural gas from the ground'.

Looking at these additional explanatory variables in more detail, we find no statistically significant difference in levels of support for shale gas development based on age or gender. We do find, however, that individuals with a third level education are less likely to support shale gas exploration, than individuals without a third level education. In terms of political orientation, individuals who describe their political beliefs as conservative as opposed to moderate or liberal were significantly more likely to support shale gas exploration. This would be in keeping with recent political rhetoric by successive conservative governments. For example, the former Prime Minister David Cameron (2013) in his op-ed in the Telegraph newspaper, stated: 'Fracking has become a national debate in Britain-and it's one that I'm determined to win'. He has also stated that without shale gas expansion, 'we could lose ground in the tough global race'. George Osborne (the former Chancellor of the Exchequer) has also expressed similar sentiments (cited in Macalister and Harvey 2013): 'I want Britain to be a leader of the shale gas revolution-because it has the potential to create thousands of jobs and keep energy bills low for millions of people'.

It is also interesting to note here that we asked respondents whether they believe the Government is for or against fracking. While the majority of respondents reported that they themselves were against fracking, it is worth noting that the vast majority of them $(79 \%)$ correctly identified that the government is in favour of 'fracking'. Just nine and $12 \%$ of respondents reported that they felt the government was against fracking or that they were unsure.

Survey respondents were asked "whether they would be willing to trade environmental sustainability for economic growth' and given a 5 point scale ranging from 1) definitely to 5) definitely not. We used individual's response to this question as a proxy for their environmental values. We find that relatively pro-environmental individuals (in this 
instance those less willing to trade off environmental sustainability for economic growth) were more likely to be against shale gas exploration. This would be reflective of the rhetoric among environmental groups such as Greenpeace and other environmental NGOs that shale gas development can have adverse environmental impacts such as climate change and air and water contamination.

In specification 3, we added in a measure of risk perception as an additional explanatory variable. Respondents were asked to indicate on a scale going from 1 to 10 (10 being most severe) the severity of risks from either 'fracking' or 'using hydraulic pressure to extract natural gas from the ground'. As one would expect, this variable was negatively and statistically significant, i.e. individuals who perceived the risks to be higher were much less likely to support shale gas exploration. The coefficients on the explanatory variables relating to socio-demographics, political orientation and environmental values were unaffected by the inclusion of this additional explanatory variable relating to risk perception. However, 'version' was no longer statistically significant and in terms of size had fallen from -0.45 to -0.16 . This suggests that, for the most part at least, the difference in the levels of support for shale gas development evident when using 'fracking' as opposed to 'using hydraulic pressure to extract natural gas from the ground' is largely due to differences in risk perception engendered in respondents. In other words, respondents perceive the risks associated with 'fracking' to be far greater than 'using hydraulic pressure to extract natural gas from the ground'. Later we examine what exactly are the major perceived risks by respondents when it comes to 'fracking'.

\subsection{Fracking versus hydraulic fracturing}

Next we examine in more detail, differences in levels of support for shale gas development for each questionnaire format (version 1 and 2). These results are presented in Fig. 1. For ease of reporting, we shorten the phrase 'using

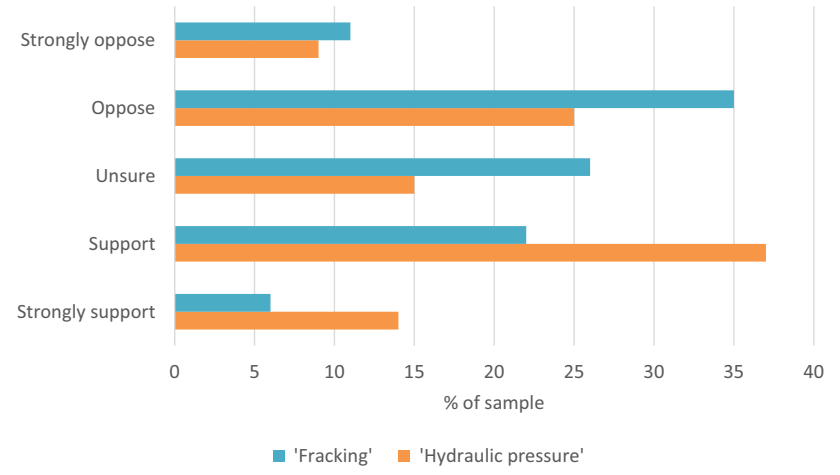

Fig. 1 Overall support for fracking/using hydraulic pressure hydraulic pressure to extract natural gas from the ground' to 'hydraulic pressure'. As can be seen in Fig. 1, whereas just $28 \%$ expressed support (somewhat in favour or strongly in favour) for 'fracking', $51 \%$ expressed support for 'hydraulic pressure'. On the other hand, $61 \%$ were either against or strongly against fracking which compares to $40 \%$ when using the synonymous descriptive term.

As briefly discussed earlier, respondents were also asked whether they believed there were any risks involved in 'fracking' or 'using hydraulic pressure'. Irrespective of which version was used, the majority of respondents felt that there were some risks involved, but there were significant differences across questionnaire formats. Whereas $86 \%$ of respondents felt that there were some risks involved in 'fracking', this compares to a figure of $68 \%$ when asked if they felt there were any risks involved in 'using hydraulic pressure'. Individuals who answered yes, i.e. felt there were some risks involved when it comes to either 'fracking' or using hydraulic fracturing', were subsequently asked to rate the severity of those risks on a scale from 1 to 10 (10 being the most severe). Respondents perceived the severity of risks associated with 'fracking' to be much more severe than that associated with 'hydraulic pressure'. For instance, the mode was 8 on the 10 point scale when using the word 'fracking' which compares to 5 when using the phrase 'hydraulic pressure'. Similar differences emerge when looking at mean sores (5.6 vs. 3.1).

Additionally, respondents were asked to make their own cost-benefit analysis of shale gas exploration. Specifically, they were asked to indicate: Which are greater: the benefits or the costs of 'fracking' or 'using hydraulic pressure to extract natural gas from the ground'? They were then given 4 options: benefits are greater, benefits and costs are equal, costs are greater or unsure. The results relating to this comparison are illustrated in Fig. 2. Although in both surveys, costs were perceived to outweigh the benefits, the percentage gap between the two registered at $26 \%$ for 'fracking' relative to just $1 \%$ for 'using hydraulic pressure'.

In the questionnaire survey, we asked respondents two open-ended questions relating to what they perceived to be

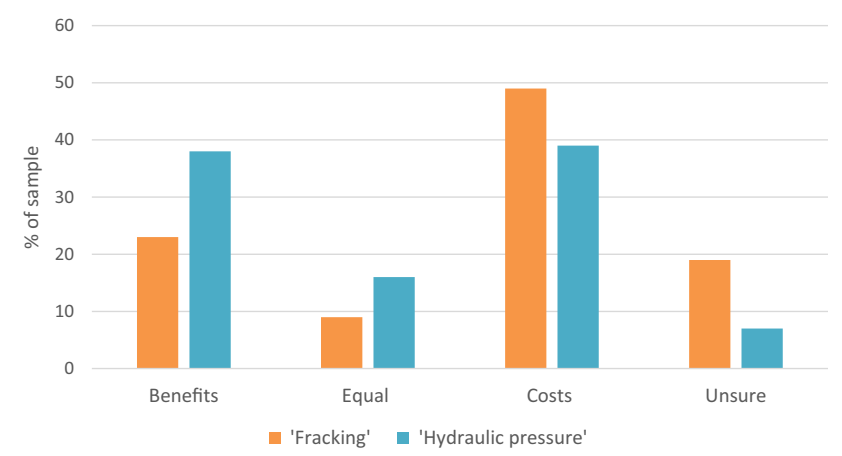

Fig. 2 Benefit-cost analysis 
the main advantages and disadvantages of 'fracking' and using 'hydraulic pressure to extract natural gas from the ground', respectively. Perceived advantages when using either 'fracking' or 'using hydraulic pressure to extract natural gas from the ground' were found to be very similar and are summarised in Table 2. The most common articulated benefits related to energy, i.e. increased energy supply, cheaper or cleaner energy. One interviewee reported that 'the UK could become an energy powerhouse', and another considered the resource to be 'essential for the future of the country'. It is also perhaps noteworthy that $21 \%$ of respondents did not report any advantages to 'fracking' or 'using hydraulic pressure to extract natural gas from the ground'.

While perceptions of advantages were broadly similar when respondents were asked to assess either 'fracking' or 'using hydraulic pressure to extract natural gas from the ground', there were notable differences when it came to perceived disadvantages (see Table 3). The most common perceived disadvantage when it came to 'fracking' was water contamination. When raising concerns surrounding water contamination, one respondent advised the interviewer to 'See Gasland'; another described how '[one can] set water on fire'. Seismicity was also a common fear when it came to fracking. These issues were much less frequently raised when respondents were considering the disadvantages of 'using hydraulic pressure to extract natural gas from the ground'.

Table 2 Perceived advantages of shale gas exploration: version 1 and 2 combined

\begin{tabular}{ll}
\hline Frequency & Benefit (categorised) \\
\hline Most & Increased energy supply/independence \\
$\downarrow$ & Cheaper energy \\
& Cleaner energy \\
& Economic growth and job provision \\
& Prevent nuclear development \\
& Renewable energy cannot be stored \\
\hline
\end{tabular}

Table 3 Perceived disadvantages of shale gas exploration

\begin{tabular}{lll}
\hline Frequency & Fracking (Survey 1) & $\begin{array}{c}\text { 'Using hydraulic pressure to } \\
\text { extract natural gas from the } \\
\text { ground' (Survey 2) }\end{array}$ \\
\hline Most & Water contamination & $\begin{array}{c}\text { Distraction to future of } \\
\text { renewables } \\
\text { Unsure/none }\end{array}$ \\
& $\begin{array}{c}\text { Uncertainty and risk } \\
\text { aversion } \\
\text { Seismicity }\end{array}$ & $\begin{array}{c}\text { Uncertainty and risk aversion } \\
\text { Deast }\end{array}$ \\
$\begin{array}{c}\text { Distraction to future } \\
\text { of renewables }\end{array}$ & Water contamination \\
\hline
\end{tabular}

Whereas water contamination, induced seismicity and fear of the unknown were the most common reported disadvantages from 'fracking', the most common reported disadvantage when it came to 'using hydraulic pressure to extract natural gas from the ground' was reflective of a general anti-fossil fuel stance, i.e. they are cleaner and cheaper options. When comparing the perceived disadvantages of both versions, one further notable difference was differences in the numbers of respondents who did not reply across both questionnaire formats. Specifically, whereas almost all participants reported at least one disadvantage associated with fracking, a significant share of respondents did not report any disadvantage when it came to "using hydraulic pressure to extract natural gas from the ground'.

While there were clear differences in perceived disadvantages in the two versions, one mutual concern expressed under both questionnaire versions was the uncertain/unknown costs associated with either 'fracking' or 'using hydraulic pressure to extract natural gas from the ground'. For example, some respondents reported a 'fear of the unknown' and 'the unknown impact' or were 'unsure of consequences to environment'.

\section{Conclusion}

In light of a boom in the profitability of extraction activities in the USA, the UK has witnessed the emergence of a nascent shale gas industry (Cotton et al. 2014). A variety of economic drivers are now in play designed to stimulate shale gas investment in the UK, and more generally, there is a policy platform described by former Prime Minister David Cameron as 'going all out for shale' (cited in Watt 2014). Although the further development of the shale gas industry in order to spur economic growth remains a key government priority, the issue has generated a great deal of controversy due to potentially significant perceived impacts. Specifically, opponents have argued that any potential economic benefits will not make up for adverse impacts on public health and the environment (Boudet et al. 2014).

Due to the contested nature of both the potential costs and benefits of shale gas exploration, this issue has attracted significant media attention in the UK. The word in popular usage taken to represent shale gas development is 'fracking', which some researchers particularly in the USA, where shale gas development is much more developed, claim engenders negative connotations in people's minds (Evensen et al. 2014b). If true, this could in turn constrain meaningful public discourse on this issue in the UK. As a useful first step in ascertaining the extent to which the word 'fracking' engenders negative connotations in the UK 
public's minds (if it does at all), we employed a split sample survey technique to compare the general public's attitudes towards shale gas development when using the word 'fracking' as compared to using the more scientifically descriptive phrase 'using hydraulic pressure to extract natural gas from the ground'.

We identified significant differences in levels of support across both questionnaire formats. Specifically, individuals were much more likely to be against shale gas development when using the word 'fracking' as opposed to when presented with 'using hydraulic pressure'. These different perceptions could manifest out of different assessments of either the risks/costs or the benefits from 'fracking' as opposed to 'using hydraulic pressure to extract natural gas from the ground'. Our analysis suggests it is primarily the former. That is, individuals feel the risks associated with shale gas development are far greater when they are presented with the word 'fracking' as opposed to 'using hydraulic pressure to extract natural gas from the ground'. The most common perceived risks include water contamination and seismicity.

We suggest that one potential explanation for differences in levels of support evident across both questionnaire formats is that limits on technical reasoning may force citizens to used cognitive heuristics (or rules of thumb) when assessing the benefits and costs of shale gas exploration. Public assessments of complex environmental issues such as the relative merits of 'fracking' may be unduly affected by media coverage which is often biased towards highlighting extreme and unusual events. Society is often faced with painful trade-offs such as whether the extra economic benefits from 'fracking' are worth the additional costs in terms of new environmental risks. Given recent media depictions, the word 'fracking' itself has biased connotations which can lead to some individuals to be 'against' fracking without properly processing the benefits and risks involved. This is not to argue that individuals are wrong in their judgement, but rather when considering the technical, scientific (and specifically environmental health) implications, they may be basing their assessments on unreliable cognitive heuristics, as opposed to careful objective analysis. This may in turn lead to an inaccurate assessment of public opinion on this matter and more generally constrain meaningful policy discussion in this area.

More generally, the British public as of yet have had few instances of actual contact with hydraulic fracturing and therefore, in order to form a well-founded opinion, are often required to use technical reasoning to comprehend scientific information. Many individuals may rely on the media to translate, frame and convey this scientific information to them (Young and Matthews 2010; Young and Dugas 2011). In the USA, where most of the literature originates, studies on media representation of this issue have, however, found coverage to be 'highly selective' (Olive 2016) and 'troubling...rather limited' (Evensen et al. 2014b). It seems likely that a similar pattern is emerging in the UK (Jaspal and Nerlich 2013).

Given the strong influence that public opinion has upon shaping policy maker preferences for controversial policy platforms (such as pro-shale gas) (Werner et al. 2015), then all parties, scientists, media and politicians need to more clearly communicate the suite of processes behind shale gas development as well as the likely costs and benefits. Of course this could be constrained by the willingness of the general public (at least certain sections of them) to ever be engaged with this subject matter and so relying on opinions in survey questionnaires may in certain instances at least be of limited value. Yet there is clearly a need for better quality engagement with heterogeneous publics on this issue (Williams et al. 2017) (and indeed other related issues regarding new technologies aimed at meeting energy security targets or mitigating the effects of climate change) in order to facilitate an informed policy-making process based on complete and sincere information as opposed to confounding and constraining prejudices.

Open Access This article is distributed under the terms of the Creative Commons Attribution 4.0 International License (http://crea tivecommons.org/licenses/by/4.0/), which permits unrestricted use, distribution, and reproduction in any medium, provided you give appropriate credit to the original author(s) and the source, provide a link to the Creative Commons license, and indicate if changes were made.

\section{References}

Andersson-Hudson J, Knight W, Humphrey M, O’Hara S (2016) Exploring support for shale gas extraction in the United Kingdom. Energy Policy 98:582-589

Argetsinger B (2011) The Marcellus Shale: bridge to a clean energy future or bridge to nowhere? Environmental, energy and climate policy considerations for shale gas development in New York State. Pace Environ Law Rev 29:321-343. http://digitalcom mons.pace.edu/pelr/vol29/iss1/8. Accessed 15 Feb 2017

Ashmoore O, Evensen D, Clarke C, Krakower J, Simon J (2016) Regional newspaper coverage of shale gas development across Ohio, New York, and Pennsylvania: similarities, differences, and lessons. Energy Res Soc Sci 11:119-132

Baron D (2006) Persistent media bias. J Public Econ 90:1-36. https:// doi.org/10.1016/j.jpubeco.2004.10.006

Birdsell D, Rajaram H, Dempsey D, Viswanathan H (2015) Hydraulic fracturing fluid migration in the subsurface: a review and expanded modelling results. Water Resour Res 51:7159-7188. https://doi.org/10.1002/2015WR017810

Bomberg E (2015) Shale we drill? Discourse dynamics in UK fracking debates. J Environ Policy Plan. https://doi.org/10.1080/ 1523908X.2015.1053111

Borick C, Rabe B, Lachapelle E (2014) Public perceptions of shale gas extraction and hydraulic fracturing in New York and Pennsylvania. Issues Energy Environ Policy 14:01-18 
Boudet H, Clarke C, Budgen D, Malbach E, Roser-Renouf C, Leiserowitz A (2014) "Fracking" controversy and communication: using national survey data to understand public perceptions of hydraulic fracturing. Energy Policy 65:57-67. https://doi.org/ 10.1016/j.enpol.2013.10.017

Brasier K, Filteau M, McLaughlin D, Jacquet J, Stedman R, Kelsey T, Goetz S (2011) Residents' perceptions of community and environmental impacts from development of natural gas in the Marcellus Shale: a comparison of Pennsylvania and New York cases. JRSS 26:32-61

Broderick J, Anderson K, Wood R, Gilbert P, Sharmina M, Footitt A, Glynn A, Nicholls F (2011) Shale gas: an updated assessment of environmental and climate change impacts. Tyndall Centre, University of Manchester. http://www.programmeofficers.co.uk/ Cuadrilla/CoreDocuments/CD40/CD40.25.PDF. Accessed 03 Apr 2017

Brown S, Gabriel S, Egging R (2010) Abundant shale gas resources: some implications of energy policy. RFF DP 10-41, resources for the future, Washington, DC. http://www.rff.org/files/sharepoint/ WorkImages/Download/RFF-DP-10-41.pdf. Accessed 18 Jan 2017

Busby C, Mangano JJ (2017) There's a world going on underground - infant mortality and fracking in Pennsylvania. J Environ Prot 8:381-393. https://doi.org/10.4236/jep.2017.84028

Cameron D (2013) We cannot afford to miss out on shale gas. The Telegraph. 11th August 2013. Accessed 12 June 2017

Christopherson SM, Frickey C, Rightor N (2013) A vote of no confidence: why local governments take action in response to shale gas development. Policy brief. CaRDI Res Policy Brief Ser 54:1-2. http://greenchoices.cornell.edu/resources/publications/ communities/Vote_of_No_Confidence_WP.pdf. Accessed 08 Sept 2017

Citi GPS (2012) Energy 2020: North America, the new Middle East? Citi GPS: global perspectives and solutions. https://csis-prod.s3. amazonaws.com/s3fs-public/legacy_files/files/attachments/ 120411_gsf_MORSE_ENERGY_2020_North_America_the New_Middle_East.pdf. Accessed 18 Jan 2017

Clarke H, Eisner L, Styles P, Turner P (2014) Felt seismicity associated with shale gas hydraulic fracturing: the first documented example in Europe. Geophys Res Lett 41:8308-8314. https://doi.org/10.1002/2014GL062047

Climek M, Brou L, Means M, Goidel K (2013) Fracking and polarization or public opinion. Louisiana State University. http:// pprllsu.com/wp-content/uploads/2015/12/Fracking-and-Polariza tion-of-Public-Opinion.pdf. Accessed 20 July 2017

Cotton M (2015) Stakeholder perspectives on shale gas fracking: a Q-method study of environmental discourses. Environ Plan A 47:1944-1962. https://doi.org/10.1177/0308518X15597134

Cotton M (2017) Fair fracking? Ethics and environmental justice in United Kingdom shale gas policy and planning. Local Environ 22(2):185-202

Cotton M, Rattle I, Van Alstine J (2014) Shale gas policy in the United Kingdom: an argumentative discourse analysis. Energy Policy 73:427-438. https://doi.org/10.1016/j.enpol.2014.05.031

Davis JJ (1995) The effects of message framing on response to environmental communications. J Mass Commun Q 72(2):285-299

Davis S, Shearer C (2014) Climate change: a crack in the natural-gas bridge. Nature 514:436-437. https://doi.org/10.1038/ nature 13927

DBEIS (2016) Natural gas: chapter 4, digest of United Kingdom energy statistics (DUKES). UK Department for Business, Energy and Industrial Strategy, London. https://www.gov.uk/govern ment/uploads/system/uploads/attachment_data/file/540923/Chap ter_4_web.pdf. Accessed 15 Apr 2017
DECC (2013) The Carboniferous Bowland shale gas study: geology and resource estimation. UK Department of Energy and Climate Change, London. https://www.ogauthority.co.uk/media/2782/ bgs_decc_bowlandshalegasreport_main_report.pdf. Accessed 31 Jan 2017

DECC (2014) The unconventional hydrocarbon resources of Britain's onshore basins - shale gas. UK Department of Energy and Climate Change, London. https://itportal.decc.gov.uk/web_files/ promote/2015/regional_reports/Promote_UK_Shalegas_2015. pdf. Accessed 21 June 2017

DECC (2016) DECC public attitudes tracker-Wave 17. UK Department of Energy and Climate Change, London. https://www.gov. uk/government/uploads/system/uploads/attachment_data/file/ 602458/PAT_wave_17_Summary_of_key_findings.pdf. Accessed 31 Mar 2017

DiGiulio D, Jackson R (2016) Impact to underground sources of drinking water and domestic wells from production well stimulation and completion practices in the Pavillion, Wyoming, Field. Environ Sci Technol 50:4524-4536. https://doi.org/10. 1021/acs.est.5b04970

Dolan P, Hallsworth M, Halpern D, King D, Metcalfe R, Vlaev I (2012) Influencing behaviour: the mindspace way. J Econ Psychol 33(1):264-277

EIA (2017a) Annual energy outlook 2017. US Department of Energy, Washington, DC. https://www.eia.gov/outlooks/aeo/pdf/ 0383(2017).pdf. Accessed 29 Aug 2017

EIA (2017b) US natural gas production. US Department of Energy, Washington, DC. https://www.eia.gov/dnav/ng/hist/n9070us2M. htm. Accessed 29 Aug 2017

Ellsworth W (2013) Injection-induced earthquakes. Science 341(6142). https://doi.org/10.1126/science.1225942. http://sci ence.sciencemag.org/content/341/6142/1225942. Accessed 24 Jan 2017

Entman R (1993) Framing: toward clarification of a fractured paradigm. J. Commun 43:51-58. https://doi.org/10.1111/j.14602466.1993.tb01304.x

Evensen D, Jacquet JB, Clarke CE, Stedman RC (2014a) What's the 'fracking'problem? One word can't say it all. Extr Ind Soc 1(2):130-136

Evensen D, Clarke C, Stedman R (2014b) A New York or Pennsylvania state of mind: social representations in newspaper coverage of gas development in the Marcellus Shale. J Environ Stud Sci 4:65-77. https://doi.org/10.1007/s13412-013-0153-9

Ferrar KJ, Kriesky J, Christen CL, Marshall LP, Malone SL, Sharma RK, Michanowicz DR, Goldstein BD (2013) Assessment and longitudinal analysis of health impacts and stressors perceived to result from unconventional shale gas development in the Marcellus Shale region. Int $\mathbf{J}$ Occup Environ Health 19:104-112. https://doi.org/10.1179/2049396713Y.000000002

Gentzkow M, Shapiro J (2006) Media bias and reputation. J Polit Econ 114:280-316. https://doi.org/10.3386/w11664

Habib S, Hinojosa MS (2016) Representation of fracking in mainstream American newspapers. Environ Pract 18(2):83-93

Hilson C (2015) Framing fracking: which frames are heard in English planning and environmental policy and practice? J Environ Law 27:177-202. https://doi.org/10.1093/jel/equ036

Holland C (2013) Earthquakes triggered by hydraulic fracturing in south-central Oklahoma. Bull Seismol Soc Am 103:1784-1792. https://doi.org/10.1785/0120120109

Howarth R, Ingraffea A, Engelder T (2011a) Natural gas: should fracking stop? Nature 477:271-275. https://doi.org/10.1038/ 477271a

Howarth R, Santoro R, Ingraffea A (2011b) Methane and the greenhouse-gas footprint of natural gas from shale formations. Clim Change 106(679). https://doi.org/10.1007/s10584-011- 
0061-5. https://link.springer.com/article/10.1007\%2Fs10584011-0061-5\#aboutcontent. Accessed 23 Jan 2017

Hultman N, Rebois D, Scholten M, Ramig C (2011) The greenhouse impact of unconventional gas for electricity generation. Environ Res Lett 6:1-9. https://doi.org/10.1088/1748-9326/6/4/049504

Jacquet JB (2014) Review of risks to communities from shale energy development. Environ Sci Technol 48:8321-8333. https://doi. org/10.1021/es404647x

Jaspal R, Nerlich B (2013) Fracking in the UK press: threat dynamics in an unfolding debate. Public Underst Sci 23:348-363. https:// doi.org/10.1177/0963662513498835

Jolls C, Sunstein CR, Thaler R (1998) Theories and tropes: a reply to Posner and Kelman. Stanf Law Rev 50:1593-1608. https://doi. org/10.2307/1229307

Kahan DM, Peters E, Wittlin M, Slovic P, Ouellette LL, Braman D, Mandel G (2012) Thepolarizing impact of science literacy and numeracy on perceived climate change risks. Nat Clim Change 2(10): 732

Kahneman D, Tversky A (1984) Choices, values and frames. Am Psychol 39:341-350. https://doi.org/10.1037/0003-066X.39.4. 341

Kohrs E (1974) Social consequences of boom growth in Wyoming. Presented at the annual meeting of the southwestern and Rocky Mountain Section, American Association for the Advancement of Science, April 24, 1974

Kovats S, Depledge M, Haines A, Fleming LE, Wilkinson P, Shonkoff SB, Scovronick N (2014) The health implications of fracking. Lancet 383:757-758. https://doi.org/10.1016/S01406736(13)62700-2

Levi M (2013) Climate consequences of natural gas as a bridge fuel. Clim Change 118:609-623. https://doi.org/10.1007/s10584-0120658-3

Macalister T, Harvey F (2013) George Osborne unveils 'most generous tax breaks in world' for fracking. The Guardian. 19th July 2013. Accessed 12 June 2017

NERA (2012) Macroeconomic impacts of LNG exports from the United States. NERA Economic Consulting, Washington, DC. http://www.nera.com/content/dam/nera/publications/archive2/ PUB_LNG_Update_0214_FINAL.pdf. Accessed 18 Jan 2017

Olive A (2016) What is the fracking story in Canada? Can Geogr 60:32-45. https://doi.org/10.1111/cag.12257

Osborn S, Vengosh A, Warner N, Jackson R (2011) Methane contamination of drinking water accompanying gas-well drilling and hydraulic fracturing. PNAS 108:8172-8176. https://doi.org/ 10.1073/pnas. 1100682108

Partridge T, Thomas M, Harthorn BH, Pidgeon N, Hasell A, Stevenson L, Enders C (2017) Seeing futures now: emergent US and UK views on shale development, climate change and energy systems. Glob Environ Change 42:1-12. https://doi.org/ 10.1016/j.gloenvcha.2016.11.002

Pater C, Baisch S (2011) Geomechanical study of Bowland Shale seismicity. Cuadrilla Resources Ltd., Lancashire. http://energy speakswv.com/Resources/Docs/Studies/Final_Report_Bowland_ Seismicity_02-11-11.pd1f. Accessed 21 June 2017

Perry SL (2012) Development, land use, and collective trauma: the Marcellus Shale gas boom in rural Pennsylvania. Cult Agric Food Environ 34:81-92. https://doi.org/10.1111/j.2153-9561. 2012.01066.x

Public Health England (2013) Review of the potential public health impacts of exposures to chemical and radioactive pollutants as a result of shale gas extraction: draft for comment. Public Health England, London. https://www.gov.uk/government/uploads/sys tem/uploads/attachment_data/file/329744/PHE-CRCE-002_for_ website_protected.pdf. Accessed: 29 Mar 2017

Royal Society and the Royal Academy of Engineers (2012) Shale gas extraction in the UK: a review of hydraulic fracturing. Royal
Society and the Royal Academy of Engineers, London. https:// royalsociety.org/ /media/policy/projects/shale-gas-extraction/ 2012-06-28-shale-gas.pdf. Accessed 01 Apr 2017

Schafft K, Borlu Y, Glenna L (2013) The relationship between Marcellus Shale gas development in Pennsylvania and local perceptions of risk and opportunity. Rural Sociol 78:143-166. https://doi.org/10.1111/ruso.12004

Siegel D, Azzolina N, Smith B, Perry A, Bothun R (2015) Methane concentrations in water wells unrelated to proximity to existing oil and gas wells in northeastern Pennsylvania. Environ Sci Technol 49:4106-4112. https://doi.org/10.1021/es505775c

Sovacool B (2014) Cornucopia or curse? Reviewing the costs and benefits of shale gas hydraulic fracturing (fracking). JRSER 37:249-264. https://doi.org/10.1016/j.rser.2014.04.068

Stoutenborough JW, Robinson SE, Vedlitz A (2016) Is "fracking" a new dirty word? The influence of word choice on public views toward natural gas attitudes. Energy Res Soc Sci 17:52-58

Theodori G (2009) Paradoxical perceptions of problems associated with unconventional natural gas development. South Rural Sociol 24:97-117

Theodori G, Luloff A, Willits F, Burnett D (2014) Hydraulic fracturing and the management, disposal and reuse of frac flowback waters: views from the public in the Marcellus Shale. Energy Res Soc Sci 2:66-74

Thomas M, Pidgeon N, Evensen D, Partridge T, Hasell A, Enders C, Herr Harthorn B, Bradshaw M (2017) Public perceptions of hydraulic fracturing for shale gas and oil in the United States and Canada. Wiley Interdiscip Rev Clim Change 8. https://doi.org/ 10.1002/wcc.450. http://onlinelibrary.wiley.com/doi/10.1002/ wcc.450/abstract. Accessed 08 Sept 2017

Thompson J (1979) The Gillette Syndrome: Myth or reality? Wyo Issues 2:30-35

Vandecasteele I, Rivero I, Sala S, Baranzelli C, Barranco R, Batelaan O, Lavalle C (2015) Impact of shale gas development on water resources: a case study in northern Poland. Environ Manag 55:1285-1299. https://doi.org/10.1007/s00267-015-0454-8

Watt N (2014) Fracking in the UK: 'we're going all out for shale, admits Cameron. Guardian. https://www.theguardian.com/envir onment/2014/jan/13/shale-gas-fracking-cameron-all-out. Accessed 08 Sept 2017

Werner AK, Vink S, Watt K, Jagals P (2015) Environmental health impacts of unconventional natural gas development: a review of the current strength of evidence. Sci Total Environ 505:1127-1141. https://doi.org/10.1016/j.scitotenv.2014.10.084

Whitmarsh L, Upham P, Poortinga W, Darnton A, McLachlan C, Devine-Wright P, Sherry-Brennan F, Demski C (2011) Public attitudes, understanding and engagement in relation to lowcarbon energy. A selective review of academic and nonacademic literatures: report for RCUK energy programme. Research Councils UK, Cardiff. http://orca.cf.ac.uk/22753/1/ EnergySynthesisFINAL20110124.pdf. Accessed 07 Apr 2017

Whitmarsh L, Nash N, Upham P, Lloyd A, Verdon J, Michael K (2015) UK public perceptions of shale gas hydraulic fracturing: the role of audience, message and contextual factors on risk perceptions and policy support. Appl Energy 160:419-430. https://doi.org/10.1016/j.apenergy.2015.09.004

Whitton J, Brasier K, Parry IM, Cotton M (2017) Shale gas governance in the United Kingdom and the United States: opportunities for public participation and the implications for social justice. Energy Res Soc Sci 26:11-22. https://doi.org/10. 1016/j.erss.2017.01.015

Wigley TM (2011) Coal to gas: the influence of methane leakage. Clim Change 108:601

Williams L, Macnaghten P, Davies P, Curtis S (2017) Framing 'fracking': exploring public perceptions of hydraulic fracturing 
in the United Kingdom. Public Underst Sci 26:89-104. https:// doi.org/10.1177/0963662515595159

Wu K, Paranjothi G, Milford J, Kreith F (2016) Transition to sustainability with natural gas from fracking. Sustain Energy Technol Assess 14:26-34. https://doi.org/10.1016/j.seta.2016.01. 003

Young N, Dugas E (2011) Representations of climate change in Canadian national print media: the banalization of global warming. Can J Sociol 48:01-22. https://doi.org/10.1111/j. 1755-618X.2011.01247.x

Young N, Matthews R (2010) The aquaculture controversy in Canada: activism, policy, and contested science. BC Studies, Vancouver (Chapter 3) 